\title{
Mathematical Model of a Bubble Column for the Increased Growth of Arthrospira platensis and the Formation of Phycocyanin
}

\author{
Hugo Fabian Lobatón García1 ${ }^{*}$, Natali López Mejía ${ }^{1}$ \\ ${ }^{1}$ Facultad de Ingeniería, Universitaria Agustiniana, Ak. 86 \#11b-95, Bogotá, Bogotá D.C., Cundinamarca, \\ postal code 110811, Colombia
}

\begin{abstract}
The objective of this research was to develop a mathematical model for batch photoautotrophic cultivation of Arthrospira platensis and to validate it against data obtained in experiments. All trials were carried at $30^{\circ} \mathrm{C}$, under a light intensity of 60 or $120 \mu \mathrm{mol} \mathrm{m}^{-2} \mathrm{~s}^{-1}$. The purpose of the model was to determine the optimal concentration of carbon dioxide, as well as to investigate the formation of phycocyanin. For the experimental conditions in this study, the optimal concentration carbon dioxide $\left(0.8 \% \mathrm{CO}_{2}, \mathrm{v} / \mathrm{v}\right)$ was predicted using the model according to the initial bicarbonate level, the carbon uptake by the microalga, the $\mathrm{pH}$, and the mass transfer process. The use of this optimal value in the gas inlet seems to be a suitable option for maintaining the optimal $\mathrm{pH}$ (9.5), thereby eliminating the need for a $\mathrm{pH}$ controller in the bioreactor system. According to the simulations, the mass fraction of the phycocyanin formation rate seems to depend on the internal light level. The percentage of adjustment obtained $\left(\mathrm{R}^{2}\right)$ was $\geq 75 \%$. The velocity of phycocyanin formation was enhanced at intensities up to $120 \mu \mathrm{mol} \mathrm{m}^{-2} \mathrm{~s}^{-1}$. However, the actual internal irradiance values were lower than the light compensation point $\left(4.5 \mu \mathrm{mol} \mathrm{m}^{-2} \mathrm{~s}^{-1}\right)$, so phycocyanin formation ceased. The mathematical model may facilitate the examination of optimal carbon delivery, as well as the light input, in several A. platensis culture conditions aimed at phycocyanin production.
\end{abstract}

Keywords: $\quad$ Arthrospira platensis; Carbon dioxide; Light intensity; Mathematical model; Phycocyanin

\section{Introduction}

Arthrospira platensis is a prokaryotic photoautotrophic cyanobacterium characterized by high levels of lipids that are currently being used as a fuel source (Jamilatun et al., 2019; Sukarni et al., 2019; Jamilatun et al., 2020). Its biomass also contains protein and other valuable substances, so A. platensis is now also cultivated to market it as complete biomass. Among the valuable compounds found in this microalga is phycocyanin, a protein of great interest to the food industry for its antioxidant capacity and to the cosmetic interest for its bright blue color. Other potential compounds of interest include $\gamma$-linoleic acid, which is an important unsaturated fatty acid, and spirulan calcium, which is a sulfated exopolysaccharide with promising biological functions (Borowitzka, 2013). A. platensis is cultivated in open cropping systems, but this cultivation method has a low biomass productivity (0.04 $\mathrm{g} \mathrm{DW} \mathrm{L}^{-1} \mathrm{~d}^{-1}$ ) (Jiménez et al., 2003) and produces a low-quality phycocyanin compared to cultivation in photobioreactors. 
Open cropping systems have a 20 -fold lower biomass production than photoreactors (Bezerra et al., 2011; Chen et al., 2013) because the environment in open ponds cannot be controlled for the variables that determine the productivity of microalgae (temperature, $\mathrm{pH}$, light intensity, nutrient levels, carbon, etc.) (Borowitzka, 2013). This control is possible in bioreactors, but the cultivation of microalgae in photobioreactors is only economically feasible if it produces an optimal yield with low investment costs, including the operation of the facility (Bertucco et al., 2014). The important aspects needed for bioreactor technology to be successful and efficient are the use of optimal strategies for carbon delivery and precision in the use of light.

A. platensis is a filamentous cyanobacterium capable of naturally forming colonies in waters that contain high levels of carbonates and bicarbonates (Binaghi et al., 2003). Therefore, increasing the production of $A$. platensis is possible by avoiding carbon limitations and taking advantage of carbon dioxide capture, since the main source of inorganic carbon of $A$. platensis is the bicarbonate ion $\left(\mathrm{HCO}_{3}^{-}\right.$) (Cornet et al., 1998). Naturally occurring bicarbonate present in the medium, which is approximately $117 \mathrm{mM}$, is taken up by the cyanobacteria and used in photosynthesis to support growth (de Morais and Costa, 2007). This uptake also controls the pH (Pawlowski et al., 2014), because the loss of dissolved carbon dioxide due to uptake into cyanobacterial cells is partly compensated by regeneration from carbonates and bicarbonates, so carbon dioxide uptake is accompanied by changes in $\mathrm{pH}$ (Rubio et al., 1999). In bubble column photobioreactors, a carbon dioxide line is opened or closed automatically according to an established $\mathrm{pH}$ set point. This implies that these reactors require pH sensors (Doucha et al., 2005; Spalding, 2008), thereby increasing investment and operating costs. However, a mathematical model for the control of $\mathrm{CO}_{2}$ supply could overcome this challenge.

One of the main functions of phycocyanin in microalgae is the capture of light; therefore, the intensity of light has an important influence on the accumulation of this phycobiliprotein (Chen et al., 2013). However, the reported optimal light intensity values required to achieve a high production of phycocyanin show no consistency, which could reflect different intensities of internal light within the culture. This discrepancy may also be a consequence of different bioreactor configurations and culture conditions (Xie et al., 2015). Again, the use of a mathematical model could aid in identifying the optimal light intensity for a particular cyanobacterial crop.

In recent years, various mathematical models have been designed and executed to simulate the growth of $A$. platensis (Cornet et al., 1992; Levert and Xia, 2001), but these models have only been validated at low cell densities $\left(<1 \mathrm{gL}^{-1}\right)$ and have not yet considered the variations in $\mathrm{pH}$ or the effects of carbon limitations on cyanobacterial cultivation. Therefore, the objective of the present research was to extend these models to conditions of high-biomass cultures of $A$. platensis growing in bubble columns, to determine the optimal supply of light necessary for the adequate formation of phycocyanin, and to test the concept of prediction of the optimal supply of carbon dioxide.

\section{Materials and Methods}

\subsection{Size of the Dataset}

Arthrospira platensis N-39 was obtained from NIES, Japan and pre-cultured in Zarrouk Medium (Aiba and Ogawa, 1977). Table 1 shows the composition of the culture medium. A $5 \mathrm{ml}$ volume was taken as a preculture and grown in an Erlenmeyer flask at $110 \mathrm{rpm}, 25^{\circ} \mathrm{C}$, and light intensity of 60 and 120 micromole $\mathrm{m}^{-2} \mathrm{~s}^{-1}$. Exponentially growing cells were used for subsequent experiments. 
Table 1 Composition of the culture medium

\begin{tabular}{lc}
\hline \multicolumn{1}{c}{ Component } & Quantity used $\left(\mathrm{gL}^{-1}\right)$ \\
\hline Solution & \\
EDTA & 0.800 \\
$\mathrm{MnSO}_{4} \cdot 4 \mathrm{H}_{2} \mathrm{O}$ & 0.002 \\
$\mathrm{Co}\left(\mathrm{NO}_{3}\right)_{2} \cdot 6 \mathrm{H}_{2} \mathrm{O}$ & 0.001 \\
$\mathrm{Na}_{2} \mathrm{MoO}_{4} \cdot 2 \mathrm{H}_{2} \mathrm{O}$ & 0.001 \\
$\mathrm{~K}_{2} \mathrm{SO}_{4}$ & 1.000 \\
$\mathrm{MgSO}_{4} \cdot 7 \mathrm{H}_{2} \mathrm{O}$ & 0.2 \\
$\mathrm{CaCl}_{2} \cdot 2 \mathrm{H}_{2} \mathrm{O}$ & 0.04 \\
$\mathrm{FeSO}_{4} \cdot 7 \mathrm{H}_{2} \mathrm{O}$ & 0.7 \\
Macronutrients & \\
$\mathrm{NaHCO}_{3}$ & 13.61 \\
$\mathrm{Na}_{2} \mathrm{CO}_{3}$ & 4.030 \\
$\mathrm{NaNO}_{3}$ & 2.500 \\
$\mathrm{NaCl}$ & 1.000 \\
$\mathrm{~K}_{2} \mathrm{HPO}_{4}$ & 0.5 \\
Boron solution $_{3}$ & \\
$\mathrm{H}_{3} \mathrm{BO}_{3}$ & 0.010 \\
Trace metal solution & 0.001 \\
$\mathrm{ZnSO}_{4} \cdot 7 \mathrm{H}_{2} \mathrm{O}$ & \\
\hline
\end{tabular}

\subsection{Bubble Column Cultivations}

The bubble column photobioreactors used to cultivate the microalgae are shown in Figure 1. A platensis was cultivated in $1 \mathrm{~L}$ bubble column photobioreactors with a gas flow rate of $48 \mathrm{Lh}^{-1}$. The gas supplied was normal air $\left(0.035 \% \mathrm{CO}_{2}\right)$ or mixtures of air and $\mathrm{CO}_{2}$ $\left(0.3 \%\right.$ and $\left.0.8 \% \mathrm{CO}_{2}, \mathrm{v} / \mathrm{v}\right)$ depending on the experimental trial (these experiments were planned in order to test the model-fitting performance). All trials were carried at $30^{\circ} \mathrm{C}$ and at light intensities of 60 or $120 \mu \mathrm{mol} \mathrm{m}^{-2} \mathrm{~s}^{-1}$ (provided by fluorescent lamps surrounding the reactor), with an initial biomass of $0.5 \mathrm{~g} \mathrm{~L}^{-1}$ and a gauge pressure of 1 bar. The inlet and outlet flows of the reactors were connected to a micro filter (Midisart $20000.2 \mu \mathrm{m}$ PTFE, Sartorius Stedim) throughout the cultivation to maintain sterile conditions.

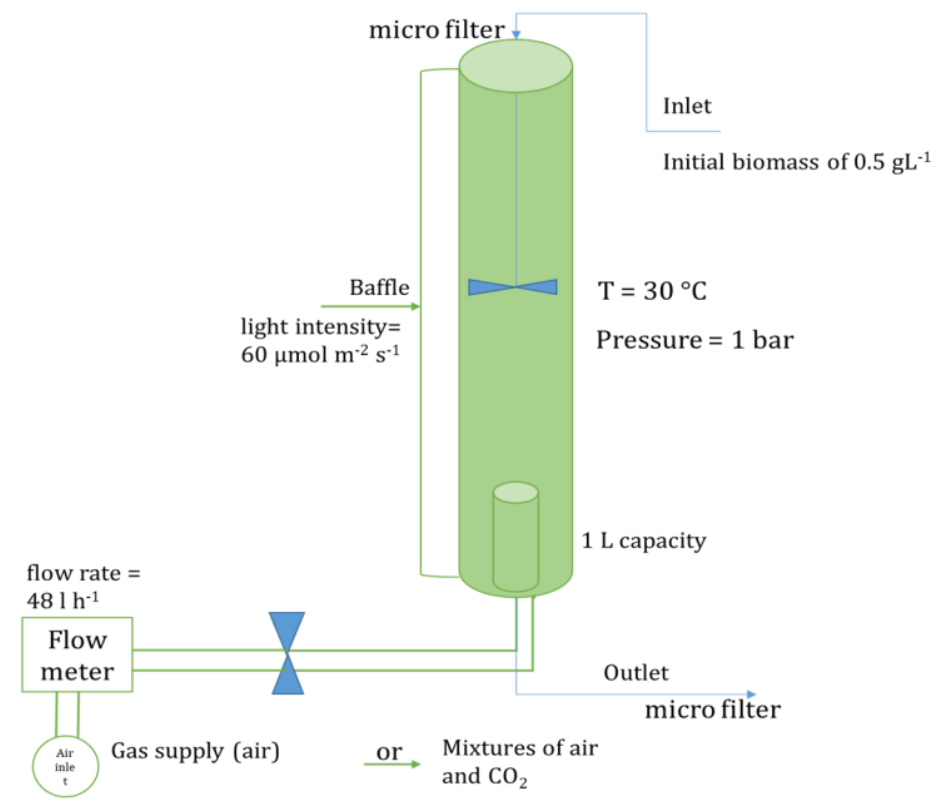

Figure 1 Bubble column photobioreactor 


\subsection{Analytic Determinations}

The collected biomass $\left(\mathrm{gL}^{-1}\right)$ was lyophilized for analysis. Characteristics of the culture broth were measured as the optical density $(750 \mathrm{~nm})$ using a spectrophotometer (Specord 210-A, Shimadzu) and the pH (MP 220, Mettler Toledo). Phycocyanin content was determined as previously described by Bennett and Bogorad (1973) and modified by Lobaton (2017).

\subsection{Mathematical Model}

A mathematical model was developed for the growth of A. platensis and for the formation of phycocyanin using the steps described by Lobaton (2017). For this, the bubble column model was considered discontinuous for the liquid phase and continuous for the gas phase. Due to the short residence time of the gas in the column, the depletion of carbon dioxide from the gas phase was disregarded. The equations used for modeling are shown in Table 2. The model was simulated in MATLAB using the parameters and conditions described by Lobaton (2017), as shown in Table 3.

Table 2 Equations used for mathematical modeling

\begin{tabular}{|c|c|c|c|}
\hline No. & Name and relation & Equation & Citation \\
\hline 1 & $\begin{array}{l}\text { Relationship between the partial pressure of } \mathrm{CO}_{2} \\
\text { and its equilibrium in the liquid phase. model } \\
\text { changes in dissolved } \mathrm{CO}_{2} \text { concentration. } \\
\mathrm{C} \text { : dissolved carbon dioxide }\left(\mathrm{gL}^{-1}\right) \\
\mathrm{C} \mathrm{CO} \text { : } \mathrm{CO}_{2} \text { concentration in gas phase (\%) } \\
\mathrm{P}: \text { Gas inlet absolute pressure (bar) } \\
\mathrm{H}_{\mathrm{CO}_{2}} \text { : Henry's constant for } \mathrm{CO}_{2}\left(\text { bar } \mathrm{L} \mathrm{mol}^{-1} \text { ) }\right. \\
\text { t: time (h) } \\
\mathrm{Kl} \text { : estimated from empirical correlation }\end{array}$ & $\frac{\mathrm{dC}}{\mathrm{dt}}=\mathrm{kl} *\left(\frac{\mathrm{P} * \mathrm{C}_{\mathrm{CO}_{2}}}{\mathrm{H}_{\mathrm{CO}_{2}}}-\mathrm{C}\right)$ & Henry's law \\
\hline 2 & $\begin{array}{l}\text { Changes in the bicarbonate depend on the rate of } \\
\text { microalgal consumption. } \\
\mathrm{B}_{0} \text { : Experimental condition } \\
\mathrm{B} \text { : Bicarbonate concentration }\left(\mathrm{gL}^{-1}\right) \\
\mathrm{y}_{\frac{\mathrm{c}}{\mathrm{x}}} \text { : theoretical yield of consumption for carbon. } \\
\frac{\mathrm{dx}}{\mathrm{dt}} \text { : change in biomass over time }\end{array}$ & $\frac{\mathrm{dB}}{\mathrm{dt}}=\mathrm{B}_{\mathrm{o}}-\mathrm{y}_{\frac{\mathrm{c}}{\mathrm{x}}} * \frac{\mathrm{dX}}{\mathrm{dt}}$ & Henry's law \\
\hline 3 & $\begin{array}{l}\text { pH calculations based on the Henderson- } \\
\text { Hasselbalch equation }\end{array}$ & $\mathrm{pH}=\mathrm{pk}+\log \left(\frac{[\mathrm{B}]}{[\mathrm{C}]}\right)$ & $\begin{array}{l}\text { Rubio et al. } \\
\text { (1999) }\end{array}$ \\
\hline 4 & $\begin{array}{l}\text { Kinetic Monod model with light, bicarbonate and } \\
\text { nitrate as limitations } \\
\mu_{\text {max }} \text { : Maximum specify growth rate }\left(\mathrm{h}^{-1}\right) \\
\text { Ki: Monod-half saturation constant of light } \\
\text { intensity for biomass }\left(\mu \mathrm{mol} \mathrm{m}^{-2} \mathrm{~s}^{-1}\right) \\
\text { Kb: Monod-half saturation constant of carbon } \\
(\mathrm{gL}-1) \\
\mathrm{K}_{\mathrm{n}} \text { : Monod-half saturation constant of nitrate }\left(\mathrm{gL}^{-1}\right) \\
\frac{\mathrm{dx}}{\mathrm{dt}} \text { : change in biomass over time }\end{array}$ & $\begin{aligned} \frac{\mathrm{dX}}{\mathrm{dt}}=\mu_{\max } & \times \frac{\mathrm{I}}{\mathrm{I}+\mathrm{K}_{\mathrm{i}}} \\
& \times \frac{\mathrm{B}}{\mathrm{B}+\mathrm{K}_{\mathrm{b}}} \\
& \times \frac{\mathrm{N}}{\mathrm{N}+\mathrm{K}_{\mathrm{n}}}\end{aligned}$ & \\
\hline 5 & $\begin{array}{l}\text { Variation of the phycocyanin content in the cell } \\
\text { Zpc: Mass fraction of phycocyanin (gphycocyanin } \\
\text { gbiomass }{ }^{-1} \text { ) } \\
\text { Rpc: Phycocyanin formation rate }\left(\mathrm{h}^{-1}\right)\end{array}$ & $\begin{aligned} \frac{d Z_{p c}}{d t}=R_{p c} \times \frac{I}{I+} & K_{i} \\
& \times \frac{N}{N+K_{n}}\end{aligned}$ & $\begin{array}{l}\text { Cornet et al. } \\
\text { (1998) }\end{array}$ \\
\hline
\end{tabular}




\begin{tabular}{|c|c|c|c|}
\hline No. & Name and relation & Equation & Citation \\
\hline 6 & $\begin{array}{l}\text { Radioactive transfer model } \\
\text { R: Bubble column radius (m) } \\
\text { I: specific intensity }\left(\mathrm{W} \cdot \mathrm{m}^{-2}\right)\end{array}$ & $\begin{array}{l}\mathrm{I}(\mathrm{r}, \mathrm{t}) \\
=\mathrm{I}_{\mathrm{S}} \times \frac{1}{\frac{\mathrm{r}}{\mathrm{R}}} \\
\times \frac{2 * \cosh \left(\delta \times \frac{\mathrm{r}}{\mathrm{R}}\right)}{\cosh (\delta)+\alpha \times \sinh (\delta)}\end{array}$ & $\begin{array}{l}\text { Cornet et al. } \\
\text { (1998) }\end{array}$ \\
\hline 7 & $\begin{array}{l}\text { Coefficient } \alpha \text { (dependence of light attenuation on } \\
\text { the biomass concentrations) }\end{array}$ & $\alpha=\left[\frac{E_{a}}{\left(E_{a} \times+E_{s}\right)}\right]^{1 / 2}$ & \\
\hline 8 & $\begin{array}{l}\text { Coefficient } \delta \text { (dependence of light attenuation on } \\
\text { the biomass concentrations) }\end{array}$ & $\begin{aligned} \delta=\left[E_{a}+E s\right] & \times \mathrm{X} \times \alpha \\
& \times \mathrm{R}\end{aligned}$ & \\
\hline 9 & $\begin{array}{l}\text { Nitrate consumption } \\
Y_{\bar{n}}: \text { theoretical yield of consumption of nitrate }\end{array}$ & $\frac{\mathrm{dN}}{\mathrm{dt}}=-\mathrm{Y}_{\frac{\mathrm{n}}{\mathrm{x}}} \times \frac{\mathrm{dx}}{\mathrm{dt}}$ & \\
\hline
\end{tabular}

Table 3 Summary of parameters and conditions used in the simulation of growth of Arthrospira platensis

\begin{tabular}{|c|c|c|c|c|c|}
\hline Parameter & $\begin{array}{l}\text { Value } \\
\text { range }\end{array}$ & $\begin{array}{l}\text { Reference/ } \\
\text { Comments } \\
\end{array}$ & Parameter & $\begin{array}{l}\text { Value } \\
\text { range }\end{array}$ & $\begin{array}{l}\text { Reference/ } \\
\text { Comments } \\
\end{array}$ \\
\hline$\mu_{\max }$ & 0.073 & $\begin{array}{l}\text { (Cornet et al., 1998; Chen et } \\
\text { al., 2013) }\end{array}$ & $\mathrm{I}_{\mathrm{o}}$ & 60 & $\begin{array}{l}\text { Experimental } \\
\text { condition }\end{array}$ \\
\hline $\mathrm{y}_{\mathrm{c} / \mathrm{x}}$ & 2.57 & (Cornet et al., 1998) & $\mathrm{R}$ & 0.025 & $\begin{array}{l}\text { Experimental } \\
\text { condition }\end{array}$ \\
\hline $\mathrm{yn} / \mathrm{x}$ & 0.45 & (Cornet et al., 1998) & $\mathrm{B}_{\mathrm{o}}$ & 9.88 & $\begin{array}{l}\text { Experimental } \\
\text { condition }\end{array}$ \\
\hline $\mathrm{K}_{\mathrm{i}}$ & 72 & $\begin{array}{l}\text { (Cornet et al., 1998; Chen et } \\
\text { al., 2013) }\end{array}$ & $\mathrm{N}_{\mathrm{Co}}$ & 1.82 & $\begin{array}{l}\text { Experimental } \\
\text { condition }\end{array}$ \\
\hline $\mathrm{Kb}$ & $3 \times 10^{-3}$ & (He et al., 2012) & $\mathrm{X}_{\mathrm{o}}$ & 0.5 & $\begin{array}{l}\text { Experimental } \\
\text { condition }\end{array}$ \\
\hline $\mathrm{pk}$ & 6.4 & (Keymer et al., 2014) & $\mathrm{k}_{\mathrm{ca}}$ & $8.9 \times 10^{3}$ & (Kern, 1960) \\
\hline $\mathrm{K}_{\mathrm{n}}$ & $5.3 \times 10^{-3}$ & (Cornet et al., 1998) & $\mathrm{P}_{\text {co }}$ & 0.4 & $\begin{array}{l}\text { Experimental } \\
\text { condition }\end{array}$ \\
\hline $\mathrm{R}_{\mathrm{pc}}$ & 0.038 & $\begin{array}{l}\text { Estimated from } \\
\text { experimental data }\end{array}$ & $\mathrm{cp}$ & 4.5 & $\begin{array}{l}\text { (Cornet et al., } \\
\text { 1998) }\end{array}$ \\
\hline $\mathrm{K}_{\mathrm{la}}$ & 30 & $\begin{array}{l}\text { Estimated from empirical } \\
\text { correlation }\end{array}$ & $\mathrm{H}_{\mathrm{CO}_{2}}$ & 30.04 & (He et al., 2012) \\
\hline $\mathrm{E}_{\mathrm{a}}$ & 250 & (Cornet et al., 1998) & $\mathrm{C}_{\mathrm{CO}_{2}}$ & $0.035-3$ & $\begin{array}{l}\text { Experimental } \\
\text { condition }\end{array}$ \\
\hline $\mathrm{E}_{\mathrm{s}}$ & 175 & (Cornet et al., 1998) & $\mathrm{P}$ & 1.0 & $\begin{array}{l}\text { Experimental } \\
\text { condition }\end{array}$ \\
\hline
\end{tabular}

\section{Results and Discussion}

\subsection{Mathematical Model Validation - Simulation of $\mathrm{CO}_{2}$ Concentration}

The model was validated with real data $\left(\mathrm{CO}_{2}\right.$ concentration and light supply) by testing two $\mathrm{CO}_{2}$ concentrations ( $3 \%$ and $0.035 \%$ ) (Figure 2a). After further simulations, an optimal carbon dioxide concentration of $0.8 \%$ was chosen for the subsequent experiments. The results showed a good adjusted $\mathrm{R}^{2}$ (coefficient of determination) between the model data and the experimental data $\left(\mathrm{R}^{2} \geq 75 \%\right)$. Figure 2 shows rapid biomass growth at $3 \% \mathrm{CO}_{2}$ at double the rate of growth compared to $0.035 \% \mathrm{CO}_{2}$. This difference is related to the high $\mathrm{pH}$ (Figure $2 \mathrm{~b}$ ) of the culture supplied with $0.035 \% \mathrm{CO}_{2}$. 

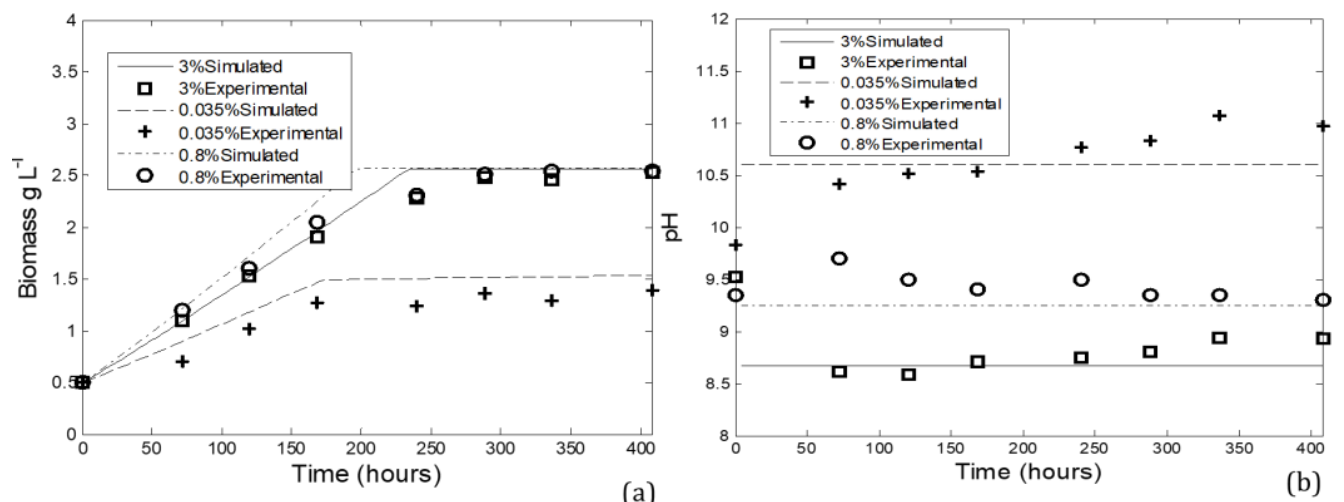

Figure 2 Simulated and experimental growth curves for Arthrospira platensis cultivated under different carbon dioxide concentrations: (a) Biomass ( $\left.\mathrm{gL}^{-1}\right)$; and (b) $\mathrm{pH}$

To preserve the electroneutrality of the culture, negative charges must be added or positive charges removed (Uusitalo, 1996) because the cyanobacteria consume bicarbonate during their growth. Bicarbonate is reduced to $\mathrm{CO}_{2}$ by the enzyme carbonic anhydrase, the $\mathrm{CO}_{2}$ is metabolized, and hydroxyl ion $\left(\mathrm{OH}^{-}\right)$is excreted into the medium. The stoichiometric relationship shown in Figure 3 depicts the one-to-one relationship between the $\mathrm{OH}^{-}$ appearance and the $\left(\mathrm{HCO}_{3}-\right)$ disappearance. When the concentration of bicarbonate decreases, it results in an increase in $\mathrm{pH}$ and a decrease in total inorganic carbon (Uusitalo, 1996). The carbon dioxide hydration rate is extremely fast $\left(8.9 \times 10^{3} \mathrm{Ms}^{-1}\right.$; Kern, 1960); so this can be neglected in the global analysis.

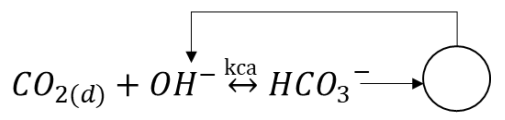

Figure 3 Stoichiometric relationship

The growth rate of the microalgal culture was affected by the concentration of $\mathrm{CO}_{2}$ because this concentration directly influences the $\mathrm{pH}$ of the medium. When the $\mathrm{CO}_{2}$ concentration was $0.035 \%$, growth was slow and the amount of biomass was low (Figure $2 \mathrm{a}$ ), and this increased the $\mathrm{pH}$ (a low partial pressure of $\mathrm{CO}_{2}$ ) (Figure $2 \mathrm{~b}$ and Figure 3). By contrast, when the $\mathrm{CO}_{2}$ concentration was $3 \%$, the $\mathrm{pH}$ decreased, and this negatively affected the specific growth rate (Table 4). The optimal growth $\mathrm{pH}$ of A. platensis is 9.5, which was achieved when the $\mathrm{CO}_{2}$ concentration was $0.8 \%$ and a slight growth was observed (Figure 4a) above that obtained with 3\% $\mathrm{CO}_{2}$ (Figure $4 \mathrm{~b}$ ), according to the simulation results. Therefore, $\mathrm{CO}_{2}$ partial pressure simulations can be used to optimize growth without the need for experimental tests and online measurements.

Table 4 Specific growth rates of Arthrospira platensis at different $\mathrm{pH}$

\begin{tabular}{ccc}
\hline $\begin{array}{c}\text { Carbon dioxide } \\
\text { concentration }\end{array}$ & $\mathrm{pH}$ & $\mu\left(\mathrm{h}^{-1}\right)^{\mathrm{a}}$ \\
\hline $3 \%$ & 8.5 & 0.0080 \\
$0.035 \%$ & 11.0 & 0.0055 \\
$0.8 \% \mathrm{~b}$ & 9.3 & 0.0095 \\
\hline
\end{tabular}

a From the experimental data

b Optimal $\mathrm{CO}_{2}$ concentration 


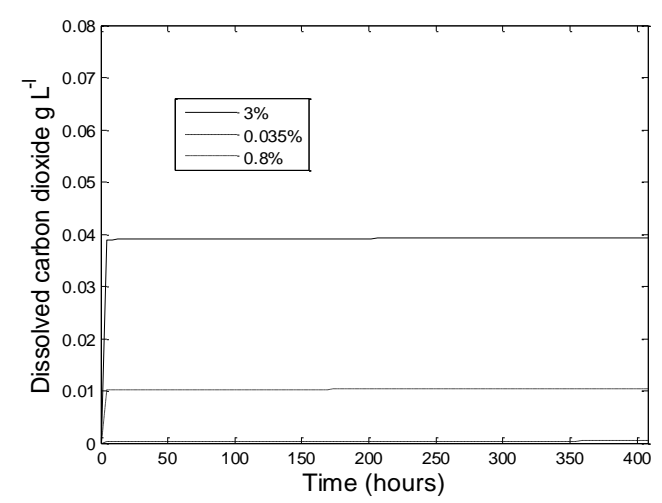

Figure 3 Predicted dissolved carbon

\subsection{Light Intensity Simulations}

The validation experiments were performed with a light intensity of $60 \mu \mathrm{mol} \mathrm{m}{ }^{-2} \mathrm{~s}^{-1}$. Comparison of the specific growth rates in the experiments indicated that the cyanobacteria appeared to be light limited, based on the experimental rate versus the specific maximum. This limitation may reflect the fact that cell density increases with the increasing light absorption.

The simulations showed that the internal light within the reactor was less than the light compensation point ( $4.5 \mu \mathrm{mol} \mathrm{m} \mathrm{m}^{-2} \mathrm{~s}^{-1}$ for A. platensis) and was $80 \%$ less after $180 \mathrm{~h}$ of culture. Figure $4 \mathrm{~b}$ shows the expected increase in growth and final biomass. The productivity of the biomass should have doubled with respect to the experimental results obtained with an illumination of $60 \mu \mathrm{mol} \mathrm{m} \mathrm{m}^{-2} \mathrm{~s}^{-1}$. In both situations, nitrate is similarly depleted after 150 to $200 \mathrm{~h}$ (Figure $4 \mathrm{~b}$ ). To maintain an optimum pH of 9.5, a carbon dioxide concentration of $1.2 \%$ was calculated for these experimental conditions.

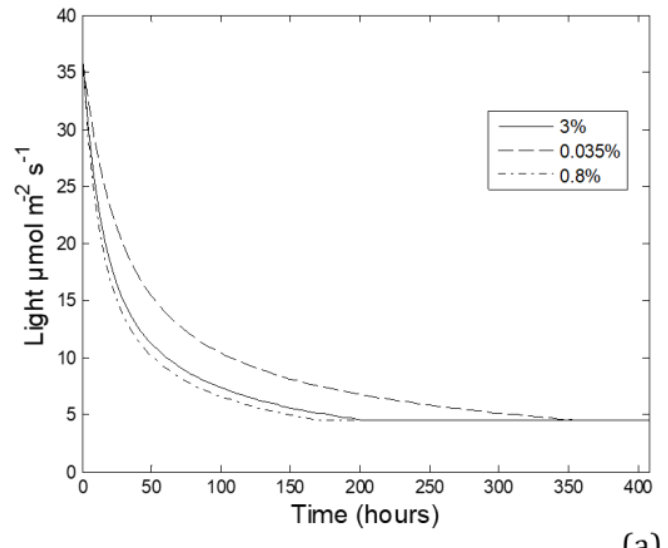

(a)

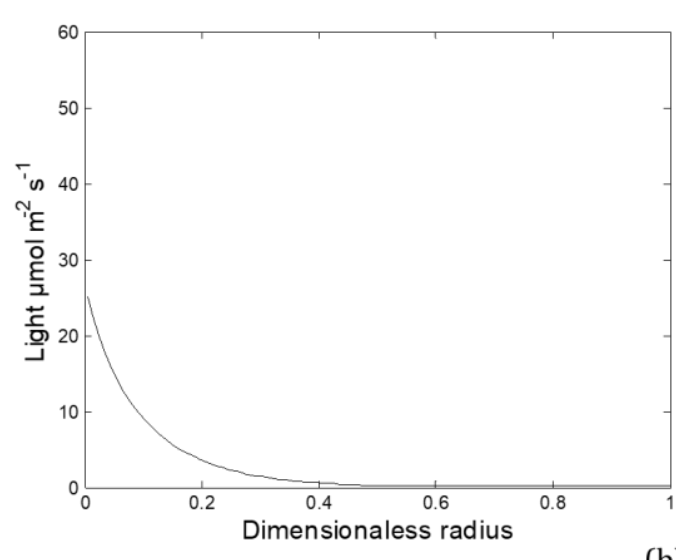

(b)

Figure 4 (a) Average internal light for each time step (superficial light intensity $60 \mu \mathrm{mol} \mathrm{m}^{-2} \mathrm{~s}^{-1}$ ) and b) Predicted light inside the reactor after 180 hours of cultivation (0: reactor wall and 1: inner part)

\subsection{Phycocyanin Dynamics}

The content of phycocyanin, as reported by Chen et al. (2013) and Xie et al. (2015), varies from 5 to $20 \%$ in $A$. platensis, with a productivity between 40 to $125 \mathrm{mg} \mathrm{L}^{-1} \mathrm{~d}^{-1}$. These values depend on parameters that influence the formation of the compound; therefore, they are included in the model. One of the influencing parameters is the $\mathrm{CO}_{2}$ concentration, as depicted in Figure 6, where the phycocyanin concentrations are determined using $\mathrm{CO}_{2}$ at $3 \%$ and $0.8 \%$ (practical experiments). Use of a concentration of $0.035 \%$ gave a higher 
growth rate and phycocyanin concentration (12\%). This could be due to the greater availability of light due to the smaller amount of biomass (Figure 5).

The production of phycocyanin is interrupted by the depletion of nitrate, which occurs after approximately 168 hours (Cornet et al., 1998; Ürek and Tarhan, 2012). When phycocyanin begins to degrade, it is converted to energy storage products such as glycogen. At this stage, the cells grow in size but do not divide. However, the model indicated that, at a light supply of $60 \mu \mathrm{mol} \mathrm{m} \mathrm{m}^{-2} \mathrm{~s}^{-1}$, nitrate is not completely depleted. This can be verified by the data shown in Figure 6, where the concentration of phycocyanin does not vary until the end of the culture period. This is why nitrate limitation was not included as a cause of phycocyanin disruption.

Nitrate and light are two important factors that influence phycocyanin production. As mentioned in the previous sections, a low light intensity near the compensation point can decrease or even stop the production of phycocyanin and consequently the production of photoautotrophic biomass. The optimal light intensity has already been studied, and it depends on the photobioreactor configuration and culture conditions. For example, it was reported that an optimal illumination of $700 \mu \mathrm{mol} \mathrm{m} \mathrm{m}^{-2} \mathrm{~s}^{-1}$ resulted in a cyanobacterial production of $125 \mathrm{mg} \mathrm{L}^{-1} \mathrm{~d}^{-1}$. On the contrary, Xie et al. (2015) report that growth was inhibited at that same light intensity. This contradiction could reflect the use of different cell densities at the beginning of the culture, as it was used $0.5 \mathrm{gL}^{-1}$ whereas Xie et al. (2015) used $0.1 \mathrm{gL}^{-1}$ as their starting culture. The mathematical model developed here, which allows the simulation of different experimental conditions, predicted a maximum internal luminous intensity of $140 \mu \mathrm{mol} \mathrm{m}^{-2} \mathrm{~s}^{-1}$ in the first situation and more than $300 \mu \mathrm{mol} \mathrm{m}^{-2} \mathrm{~s}^{-1}$ in the second case. Therefore, an internal light intensity up to $140 \mu \mathrm{mol} \mathrm{m}^{-2} \mathrm{~s}^{-1}$ can be predicted to improve the rate of phycocyanin formation. However, higher values of internal irradiance can adversely affect phycocyanin production. At light intensities of $120 \mu \mathrm{mol} \mathrm{m}^{-}$ ${ }^{2} \mathrm{~s}^{-1}$, the biomass productivity was twice that obtained at $60 \mu \mathrm{mol} \mathrm{m} \mathrm{m}^{-2} \mathrm{~s}^{-1}$.
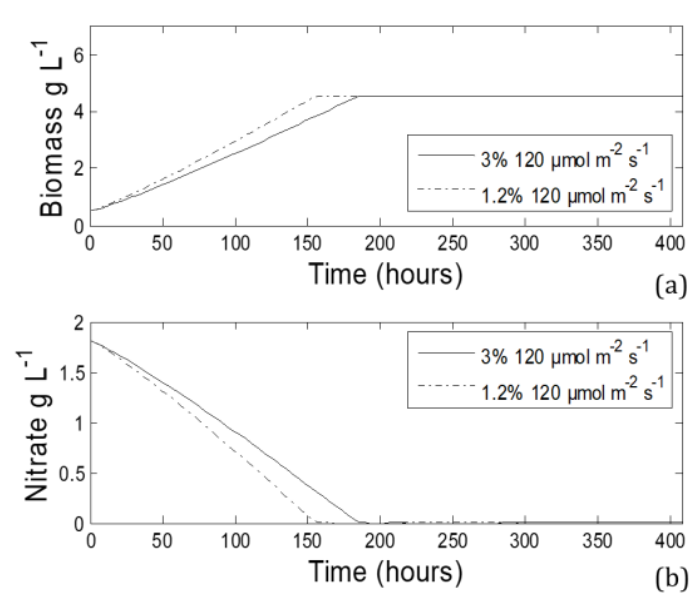

Figure 5 (a) Predicted biomass; and (b) nitrate

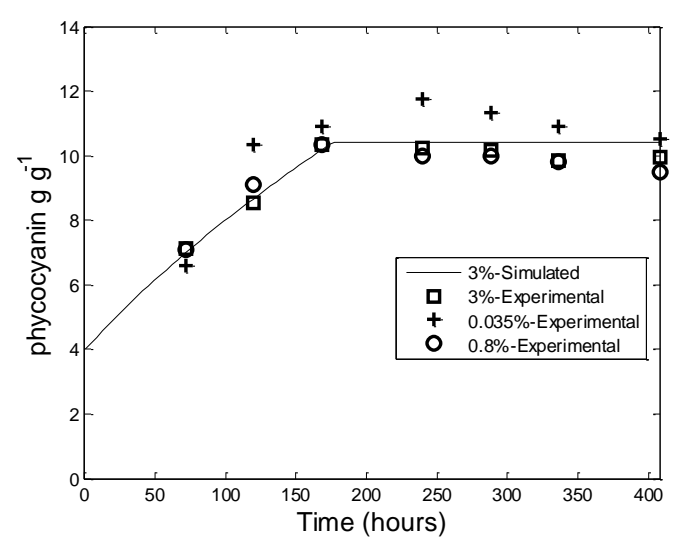

Figure 6 Experimental phycocyanin mass fraction (Superficial light intensity $60 \mu \mathrm{mol} \mathrm{m}^{-2} \mathrm{~s}^{-1}$ )

\section{Conclusions}

The biomass growth and $\mathrm{pH}$ variations predicted with the model agree with the experimental measurements. Cultivations with either $3 \%$ or $0.035 \% \mathrm{CO}_{2}$ led to a suboptimal $\mathrm{pH}$, so the model was used to determine a $\mathrm{CO}_{2}$ concentration that results in an optimal pH of 9.5. For the experimental conditions in this work $\left(60 \mu \mathrm{mol} \mathrm{m}^{-2} \mathrm{~s}^{-1}\right)$, a $0.8 \%$ $\mathrm{CO}_{2}$ concentration was selected. A sensitive analysis with higher light intensity $(120 \mu \mathrm{mol}$ 
$\mathrm{m}^{-2} \mathrm{~s}^{-1}$ ) showed an increment in the biomass productivity, as well as in the optimal $\mathrm{CO}_{2}$ concentration $\left(1.2 \% \mathrm{CO}_{2}\right)$. The mass fraction of phycocyanin was produced at a rate that was mainly controlled by the internal light in the photobioreactor before nitrate limitations appeared. At light intensities of $120 \mu \mathrm{mol} \mathrm{m}^{-2} \mathrm{~s}^{-1}$, the biomass productivity was two times greater than the experimental results at $60 \mu \mathrm{mol} \mathrm{m}^{-2} \mathrm{~s}^{-1}$. According to the simulations, the average internal light should be between $140 \mu \mathrm{mol} \mathrm{m}^{-2} \mathrm{~s}^{-1}$ and $4.5 \mu \mathrm{mol} \mathrm{m}^{-2} \mathrm{~s}^{-1}$ (the $\mathrm{CO}_{2}$ compensation point for $A$. platensis). Lower or higher values seem to have an adverse effect on the phycocyanin mass fraction.

In summary, the mathematical model proposed here can help to eliminate the need for $\mathrm{pH}$ sensing in cyanobacterial cultivation by forecasting the $\mathrm{CO}_{2}$ level required to regulate the $\mathrm{pH}$. The results showed a good adjusted $\mathrm{R}^{2}$ (coefficient of determination) between the model data and the experimental data $\left(\mathrm{R}^{2} \geq 75 \%\right)$. The model can support the investigation of other culture conditions (i.e., light intensity) or photobioreactor modifications (i.e., light path) and their influence on phycocyanin production.

\section{References}

Aiba, S., Ogawa, T., 1977. Assessment of Growth Yield of a Blue-green Alga, Spirulina platensis, in Axenic and Continuous Culture. Journal of General Microbiology, Volume 102(1), pp. 179-182

Bennett, A., Bogorad, L., 1973. Complementary Chromatic Adaptation in a Filamentous Blue-green Alga. The Journal of Cell Biology, Volume 58(2), pp. 419-435

Bertucco, A., Beraldi, M., Sforza, E., 2014. Continuous Microalgal Cultivation in a Laboratory-Scale Photobioreactor Under Seasonal Day-night Irradiation: Experiments and Simulation. Bioprocess and Biosystems Engineering, Volume 37(8), pp. 1535-1542

Bezerra, R.P., Montoya, E.Y.O., Sato, S., Perego, P., de Carvalho, J.C.M., Converti, A., 2011. Effects of Light Intensity and Dilution Rate on the Semicontinuous Cultivation of Arthrospira (Spirulina) platensis. A Kinetic Monod-type Approach. Bioresource Technology, Volume 102(3), pp. 3215-3219

Binaghi, L., Del Borghi, A., Lodi, A., Converti, A., Del Borghi, M., 2003. Batch and Fed-batch Uptake of Carbon Dioxide by Spirulina platensis. Process Biochemistry, Volume 38(9), pp. 1341-1346

Borowitzka, M., 2013. High-value Products from Microalgae-Their Development and Commercialisation. Journal of Applied Phycology, Volume 25(3), pp. 743-756

Chen, C.Y., Kao, P.C., Tsai, C.J., Lee, D.J., Chang, J.S., 2013. Engineering Strategies for Simultaneous Enhancement of C-phycocyanin Production and $\mathrm{CO}_{2}$ Fixation with Spirulina platensis. Bioresource Technology, Volume 145, pp. 307-312

Cornet, J.F., Dussap, C.G., Cluzel, P., Dubertret, G., 1992. A Structured Model for Simulation of Cultures of the Cyanobacterium Spirulina platensis in Photobioreactors: II. Identification of Kinetic Parameters under Light and Mineral Limitations. Biotechnology and Bioengineering, Volume 40(7), pp. 826-834

Cornet, J.F., Dussap, C.G., Gros, J.B., 1998. Kinetics and Energetics of Photosynthetic Microorganisms in Photobioreactors. In: Bioprocess and Algae Reactor Technology, Apoptosis, Advances in Biochemical Engineering Biotechnology, Volume 59, Springer, Berlin Heidelberg, Germany, pp. 153-224

de Morais, M.G., Costa, J.A.V., 2007. Biofixation of Carbon Dioxide by Spirulina sp. and Scenedesmus obliquus Cultivated in a Three-stage Serial Tubular Photobioreactor. Journal of Biotechnology, Volume 129(3), pp. 439-445 
Doucha, J., Straka, F., Livansky, K., 2005. Utilization of Flue Gas for Cultivation of Microalgae (Chlorella sp.) in an Outdoor Open Thin-layer Photobioreactor. Journal of Applied Phycology, Volume 17(5), pp. 403-412

He, L., Subramanian, V.R., Tang, Y.J., 2012. Experimental Analysis and Model-based Optimization of Microalgae Growth in Photo-bioreactors using Flue Gas. Biomass and Bioenergy, Volume 41, pp. 131-138

Jamilatun, S., Budhijanto, B., Rochmadi., Yuliestyan, A., Budiman, A., 2019. Effect of Grain Size, Temperature and Catalyst Amount on Pyrolysis Products of Spirulina platensis Residue (SPR). International Journal of Technology, Volume 10(3), pp. 541-550

Jamilatun, S., Budhijanto, Rochmadi, Yuliestyan, A., Aziz, M., Hayashi, J., Budiman, A., 2020. Catalytic Pyrolysis of Spirulina platensis Residue (SPR): Thermochemical Behavior and Kinetics. International Journal of Technology, Volume 11(3), pp. 522-531

Jiménez, C., Cossío, B.R., Niell, F.X., 2003. Relationship Between Physicochemical Variables and Productivity in Open Ponds for the Production of Spirulina: A Predictive Model of Algal Yield. Aquaculture, Volume 221(1-4), pp. 331-345

Kern, D.M., 1960. The Hydration of Carbon Dioxide. Journal of Chemical Education, Volume 37(1), pp. 1-14

Keymer, P., Lant, P., Pratt, S., 2014. Modelling Microalgal Activity as a Function of Inorganic Carbon Concentration: Accounting for the Impact of $\mathrm{pH}$ on the Bicarbonate System. Journal of Applied Phycology, Volume 26(3), pp. 1343-1350

Levert, J.M., Xia, J., 2001. Modeling the Growth Curve for Spirulina (Arthrospira) maxima, a Versatile Microalga for Producing Uniformly Labelled Compounds with Stable Isotopes. Journal of Applied Phycology, Volume 13(4), pp. 359-367

Lobaton, H.F.G., 2017. Mathematical Modelling as a Research Tool in the Cyanobacteria. Dissertation. Graduate Program, Friedrich-Alexander-Universität Erlangen-Nürnberg, Germany

Miller, A.G., Colman, B., 1980. Evidence for $\mathrm{HCO}_{3}^{-}$Transport by the Blue-Green Alga (Cyanobacterium) Coccochloris peniocystis. Plant Physiology, Volume 65(2), pp. 397402

Pawlowski, A., Fernández, I., Guzmán, J.L., Berenguel, M., Acién, F.G., Normey-Rico, J.E., 2014. Event-based Predictive Control of $\mathrm{pH}$ in Tubular Photobioreactors. Computers and Chemical Engineering, Volume 65, pp. 28-39

Rubio, F.C., Acien, F.G., Sanchez, J.A., Garcia, F., Molina, E., 1999. Prediction of Dissolved Oxygen and Carbon Dioxide Concentration Profiles in Tubular Photobioreactors for Microalgal Culture. Biotechnology and Bioengineering, Volume 62(1), pp. 71-86

Spalding, M.H., 2008. Microalgal Carbon-dioxide-concentrating Mechanisms: Chlamydomonas Inorganic Carbon Transporters. Journal of Experimental Botany, Volume 59(7), pp. 1463-1473

Sukarni, S., Sumarli, S., Nauri, I.M., Prasetiyo, A., Puspitasari, P., 2019. Thermogravimetric Analysis on Combustion Behavior of Marine Microalgae Spirulina Platensis Induced by $\mathrm{MgCO}_{3}$ and $\mathrm{Al}_{2} \mathrm{O}_{3}$ Additives. International Journal of Technology, Volume 10(6), pp. 1174-1183

Ürek, R.Ö., Tarhan, L., 2012. The Relationship Between the Antioxidant System and Phycocyanin Production in Spirulina maxima with Respect to Nitrate Concentration. Turkish Journal of Botany, Volume 36(4), pp. 369-377

Uusitalo, J., 1996. Algal Carbon Uptake and the Difference Between Alkalinity and High pH ("alkalization"), Exemplified with a pH Drift Experiment. Scientia Marina, Volume $60(1)$, pp. $129-134$ 
Xie, Y., Jin, Y., Zeng, X., Chen, J., Lu, Y., Jing, K., 2015. Fed-batch Strategy for Enhancing Cell Growth and C-phycocyanin Production of Arthrospira (Spirulina) platensis Under Phototrophic Cultivation. Bioresource Technology, Volume 180, pp. 281-287 